TITLE:

\title{
Impaired empathic abilities and reduced white matter integrity in schizophrenia(Abstract_要旨)
}

\author{
AUTHOR(S): \\ Fujino, Junya
}

\section{CITATION:}

Fujino, Junya. Impaired empathic abilities and reduced white matter integrity in schizophrenia. 京都大学, 2016, 博士(医学)

\section{ISSUE DATE:}

2016-03-23

URL:

https://doi.org/10.14989/doctor.k19554

RIGHT: 


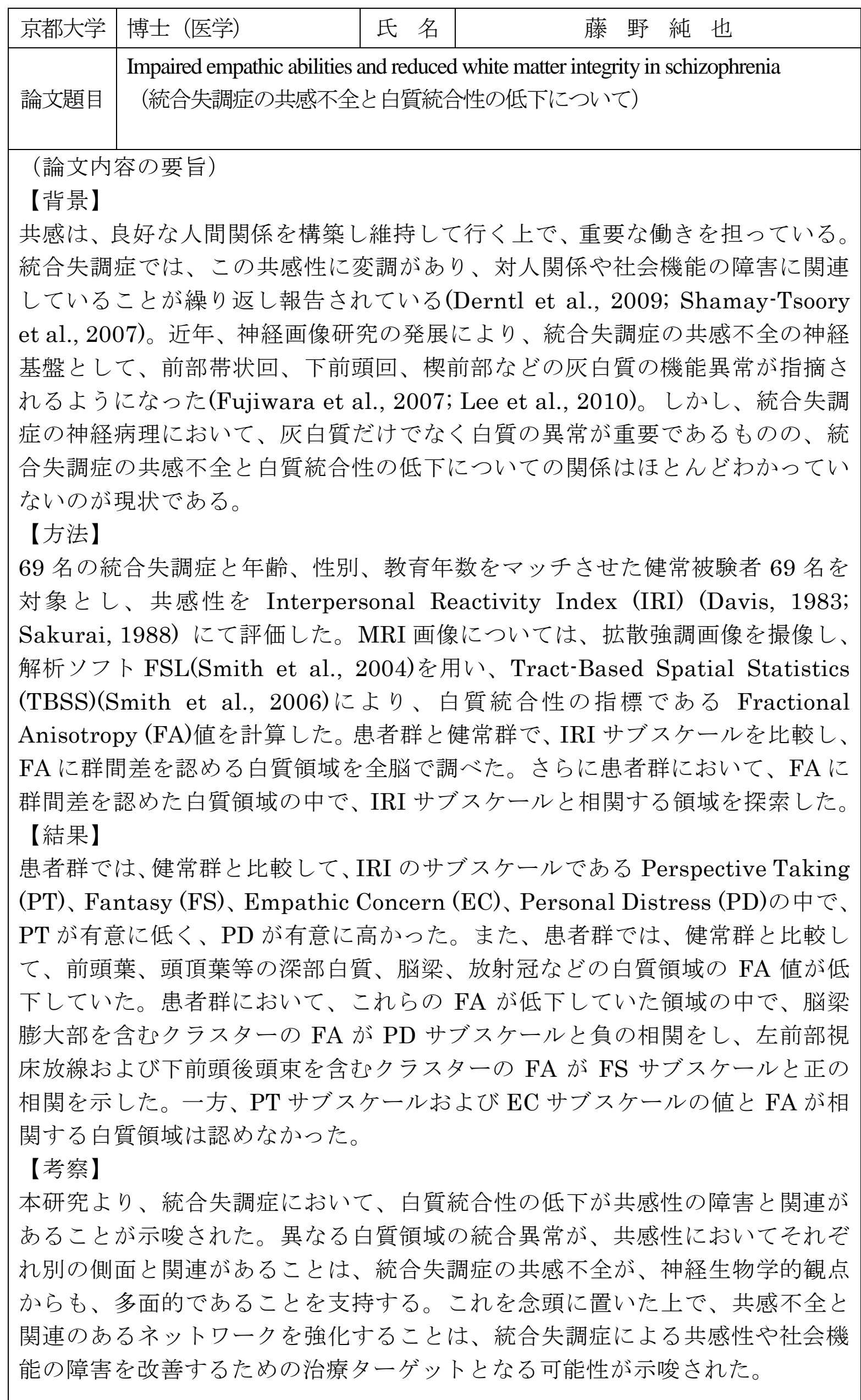

\section{(論文審査の結果の要旨)}

共感性は、良好な人間関係を築く上で重要な役割を担っている。統合失調症では、 共感不全と白質構造異常が繰り返し報告されているが、両者の関係はほとんどわかって いない。本研究では、統合失調症において、共感不全と白質統合性低下との関連を、MRI を用いて検討した。69名の統合失調症群と、年齢、性別、教育年数がマッチした 69 名の 健常対照群を対象とし、共感性を Interpersonal Reactivity Index (IRI)を用いて多 次元的に評価した。MRI 画像については、拡散強調画像を撮像し、Tract-Based Spatial Statistics (TBSS)により、白質統合性の指標である Fractional Anisotropy（FA）值を計算した。患者群と健常群で、IRI のサブスケールを比較 し、IRI のサブスケールと FA 值が相関する白質領域を探索した。結果、患者群 において、脳梁膨大部を含むクラスターの FA が IRI の Personal Distress サブ スケールと負の相関をし、左前部視床放線および下前頭後頭束を含むクラスタ 一の FA が Fantasy サブスケールと正の相関を示した。本研究の結果は、統合 失調症の共感不全の多面性を神経生物学的観点からも支持し、統合失調症にお ける共感不全と白質構造異常の関係の詳細を明らかにした。

以上の研究は、統合失調症の共感不全の神経基盤の解明に貢献し、同疾患 の病態解明に寄与するところが多い。

したがって、本論文博士 (医学) の学㕸論文として価值あるものと認める。

なお、本学位授与申請者は、平成 27 年 12 月 7 日実施の論文内容とそれに関連し た試問を受け、合格と認められたものである。 